\title{
Labour markets in Russia, Belarus and Kazakhstan
}

\begin{abstract}
Labour markets are a key element of an economy as they determine what proportion of the population is employed and what areas need attention in terms of getting more of the labour force into work. The performance of the labour market reflects how well the economy is functioning as a whole. Indeed, economic growth is the sum of productivity growth and labour force growth: less of the latter makes it harder to grow faster, creating a vicious cycle of weak GDP growth, weak job growth and low labour force participation. This clearly illustrates that the labour market plays a key role in the overall growth of an economy. In this article, the authors focus on the experience of Russia, Belarus and Kazakhstan and how their labour markets function, concluding that the key priorities for all these governments is the proper allocation of resources, such that the quality of the labour force is enhanced and matches the precise areas of labour demand, as well as living standards enhanced and workers' rights protected.
\end{abstract}

Keywords: labour markets, financial crisis, wage growth, transition, skills

\section{Labour markets before the 2007/08 recession}

In the period before the 2007/08 financial crisis, there was globalisation, greater labour mobility and more liberalisation of employee-employer relations. Over the past decade, employment protection has declined, a feature visible in regulatory changes concerning individual and collective job dismissals (OECD, 2013). These factors have, in general, increased labour and product market flexibility and, when output changed, more of the adjustment took place through employment (Daly et al, 2013). This highlights that, before the crisis emerged in 2007, there was mobility and better regulation in the labour market. Thus, the labour market was performing well and the economy was, as a result, in good shape: unemployment was down; wage rates up; and people had jobs which, in addition, correlates with good economic performance.

Figure 1 shows a comparison between Russia, Belarus and Kazakhstan in terms of each country's percentage growth in GDP, the unemployment rate and the current account to GDP ratio in January 2014. We can see that, with the growth of the economy being on the slow side, the unemployment rate has been on the rise, suggesting that many people who are looking for jobs and work are struggling to find it. The cases of Russia and Belarus are particularly apparent from the graph below. 
Figure 1 - Comparison of GDP growth, unemployment rate and the current account to GDP ratio (January 2014, \%)

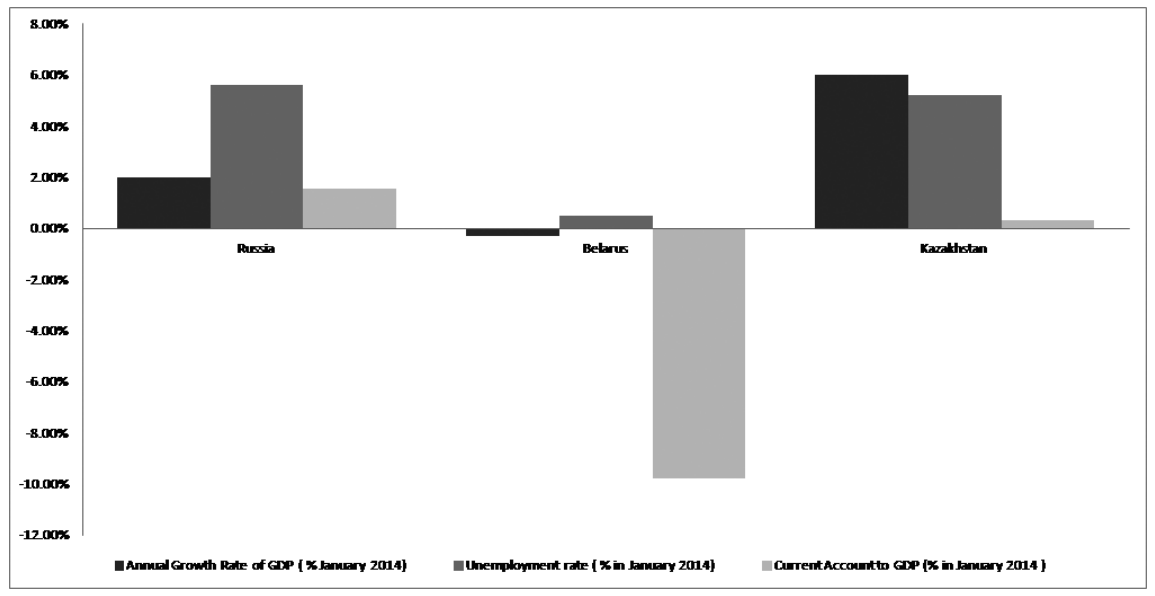

Source: http://www.tradingeconomics.com/kazakhstan/current-account-to-gdp

In addition, considering the current account to GDP ratio tells us how competitive a country is on the international level in terms of trading, domestic demand, etc. We can see that, in the case of Russia, its current account to GDP ratio is on the low side, suggesting that Russia is heavily dependent on imports and that domestic demand is strong. This means that Russia is obtaining more goods and services from abroad compared to such products being created in its own country. This highlights an outwards flow of capital and a trade deficit as well as, hence, a lack of job opportunities in the domestic market which would compel people to migrate to other countries.

However, the Kazakhstan case demonstrates the opposite, of a rapidly-growing GDP and a low unemployment rate.

This illustrates that, where an economy is performing well, the domestic market of a country also does well, with more jobs and greater productivity. Domestic industries are much stronger, allowing the country to export its goods and services, increasing the inwards flow of capital and creating a much healthier and stronger economy. This demonstrates how the economy and the labour market work side-by-side.

\section{Labour market in Russia}

Russia, a country of $142 \mathrm{~m}$ people, currently has an unemployment rate of less than six per cent. Within the country, most of the economic activity takes place in two cities - Moscow and St. Petersburg - with these two cities constituting the major part of Russia's workforce and the heart of its labour market. Moscow has $10.4 \mathrm{~m}$ inhabitants (unofficially, $16 \mathrm{~m}$ ); while St. Petersburg has $4.6 \mathrm{~m}$ inhabitants $(6.5 \mathrm{~m}$ unofficially). Around eighty per cent of the population of Russia lives in the European part, while $75.5 \mathrm{~m}$ Russians are the economically active population, of which women make up around $49 \%$. 
Gimpelson and Kapeliushnikov (2011) note:

The Russian case is of special interest due to the high heterogeneity of the country and the lack of a tradition of obedience to the law. As M. Saltykov-Tchedr put it in the XIX century, the stringency of Russian laws is offset by their non-observance. Non-observance of laws and rules is a key element of the observed flexibility. Weak enforcement (which reflects weak capacity of the state) concerns all major wage and employment regulations.

This shows the faults of the Russian labour market. It indicates that there is a tradition of a lack of observance of the law in the country; and, hence, little regulation or enforcement of laws in the area of the labour market.

A 2003 report by Izdatelstvo Ves Mir for the International Bank for Reconstruction and Development and the World Bank (2003) identifies:

One of the main challenges confronting the Russian Federation today is to increase real wages and productive employment in order to improve the standard of living of its population.

It goes on to take into account the macroeconomic policies which Russia should implement to put its labour market on the path to recovery, pointing out that:

Macroeconomic policies that promote competitive markets raise aggregate demand for new jobs, and improvements in labour productivity may have the most critical impact on employment and wage outcomes.

Hence, this identifies the need for Russia to construct a policy which would help to create competition, raise demand for labour and also increase labour productivity.

Tables 1 and 2 show recent figures for Russian GDP and the unemployment rate:

Table 1 - GDP growth in 2012, 2013 and forecast for 2014 (\%)

\begin{tabular}{|l|c|c|c|}
\hline & $\mathbf{2 0 1 2}$ & $\mathbf{2 0 1 2}$ & $\mathbf{2 0 1 4}$ \\
\hline Globe & 3.1 & 3.7 & 3.3 \\
\hline Russia & 4.8 & 2.1 & 2.0 \\
\hline
\end{tabular}

Source: http://data.worldbank.org/indicator/NY.GDP.MKTP.KD.ZG 
Table 2 - Russia's unemployment rate (\%) in 2013 and forecast for 2014

\begin{tabular}{|l|c|}
\hline & Unemployment rate (\%) \\
\hline August 2013 & 5.3 \\
\hline September 2013 & 5.2 \\
\hline October 2013 & 5.3 \\
\hline November 2013 & 5.5 \\
\hline December 2013 & 5.4 \\
\hline January 2014 & 5.6 \\
\hline February 2014 & 5.6 \\
\hline March 2014 & 5.6 \\
\hline April 2014 & 5.4 \\
\hline May 2014 & 5.3 \\
\hline
\end{tabular}

Source: http://www.tradingeconomics.com/russia/unemployment-rate

We can see some evidence of recovery which is due to the measures that the Russian government took during the late 1990s to assist the recovery of the Russian economy. A few of these measures were to establish public confidence in the government which had been lost; stabilise the currency and the banking sector, to provide a flow of credit to the productive sector; and also to control the rise in prices in the energy and transport sector.

In the long run, Russia should try to construct better enforcement of the labour law so as to provide assistance in the adjustment of wages and employment. The Izdatelstvo Ves Mir report discusses some key points regarding the solution to Russia's labour market, commenting thus as regards some of the major items of concern:

1) Russia spends more on programs, such as training and job creation, which are generally considered by international experts as cost-ineffective and spends less on cost-effective job counseling and information programs. (2) The focus of ALMPs is on younger workers rather than older, experienced, and less-educated workers who comprise the majority of the longterm unemployed. (International Bank for Reconstruction and Development/World Bank (2003): 24)

This highlights a few of the important things that Russia must look at. The report points out that Russia should focus on its younger population and help train it for the upcoming challenges; and that it should focus on programmes that do not cost more than they should. These particular aspects may help move the Russian labour market in the right direction and prepare it for its future challenges. 


\section{Labour market in Belarus}

The country suffered economic decline after 1991. The BBC website has a Belarus Profile which reports thus:

... with independence came economic decline. President Lukashenko has steadfastly opposed the privatization of state enterprises. Private business is virtually non-existent. Foreign investors stay away. The economic situation deteriorated drastically in the summer of 2011 when a balance of payments crisis drained the country's hard-currency reserves. The government's efforts to re-peg the official exchange rate and freeze the price of staple foodstuffs failed to impress either Russia or the International Monetary Fund, to both of which Belarus appealed for assistance.

These are some of the economic drawbacks from which the country has had to suffer since its independence.

The Belarusian labour market has an important role to play in its economy getting back on track. The analyst Ryhor Astapenia posits:

Increasing demand for skilled workers in the entire country has stopped the stream of labour emigration of Belarusians to Russia and the West. However, the recovering labour market has not cured itself of its old illnesses. The state-run economy uses its financial and human resources inadequately and limits potential growth. While building industry demands people, many manufacturers need to fire some.

The government in Belarus has not used its resources properly and has focused on personal gains that have badly affected the labour market in Belarus.

Table 3 shows us the unemployment rate of Belarus in the years after 2005. We can see that, since 2005, the unemployment rate has been on a downwards trend. This ought to signify that the economy is heading in the right direction, with more people able to get jobs in the country. If the government in Belarus was able to maintain these figures, then the country ought to be able to establish economic prosperity and growth in the future. 
Nina Lazaridi, Badr Aziz and Bruno S. Sergi

Table 3 - Unemployment rate in Belarus

\begin{tabular}{|l|c|}
\hline & Unemployment rate (\%) \\
\hline 2005 & 1.9 \\
\hline 2006 & 1.5 \\
\hline 2007 & 1.1 \\
\hline 2008 & 1.0 \\
\hline 2009 & 0.8 \\
\hline 2010 & 0.9 \\
\hline 2011 & 0.7 \\
\hline 2012 & 0.6 \\
\hline 2013 & 0.5 \\
\hline 2014 (Estimate) & 0.5 \\
\hline
\end{tabular}

Source: http://www.tradingeconomics.com/belarus/unemployment-rate

Furthermore, the employed population of Belarus has been reasonably static, albeit falling to a lower level in the last three years. At a time of a falling unemployment rate, the employed population ought, in theory, to be rising, so it is clear that there are some difficulties in the figures which need to be explained alternatively.

Table 4 - Belarus employed population

\begin{tabular}{|l|c|}
\hline & Employed population \\
\hline 2005 & 4512.6 \\
\hline 2006 & 4517.3 \\
\hline 2007 & 4520.6 \\
\hline 2008 & 4509.0 \\
\hline 2009 & 4516.4 \\
\hline 2010 & 4508.0 \\
\hline 2011 & 4501.1 \\
\hline 2012 & 4482.5 \\
\hline 2013 & 4487.0 \\
\hline 2014 (Estimate) & 4485.5 \\
\hline
\end{tabular}

Source: http://www.tradingeconomics.com/belarus/employed-persons 


\section{Labour market in Kazakhstan}

Kazakhstan was a planned economy during the Soviet era, with everything owned by the state. Even the labour force was employed by the state. Economists Tatibekov, Adams and Prochaska (2004) focus their attention on the labour market and human resource management practices in Kazakhstan where, out of a total population of circa $16.3 \mathrm{~m}$ people, nearly $7.3 \mathrm{~m}$ were in the labour force. In $1990,93 \%$ of the labour force was employed in the state sector, with the remaining seven per cent in the non-state sector. Thus, the economy was one run completely by the state: the majority of the labour force was either in the state industrial (22\%), agricultural (18\%) or construction $(12 \%)$ sectors; with $10 \%$ employed in transportation and $8 \%$ in trade.

Upon establishing its sovereignty in 1991, Kazakhstan's leadership has devised a series of programmes to foster the development of the labour market. The state established public employment services; introduced vocational training and educational programmes; devised ways to encourage job creation; and designed a system of unemployment benefits. Over the course of post-Soviet development, these programmes have evolved into a sophisticated and more efficient system of incentives and benefits, such as the 'bridging policies' designed to prevent lay-offs through wage subsidies, the creation of temporary employment opportunities and the promotion of job creation in rural areas or environmentally-devastated zones.

The major issues that concern the development of the labour market in Kazakhstan today are youth unemployment, informal employment and illegal labour migration. In 2013 , the official level of unemployment among young people (aged 15-28) was 5.5\%; however, the logistical methods of the registration of unemployed individuals lead us to believe that the real numbers are much higher. ${ }^{1}$ About one-quarter to one-third of this pool is not engaged in the market due to having a low level of qualifications or a difficulty in finding jobs that match their skills set despite having a formal education. It is estimated that about eleven per cent of the group either have not pursued, or have not finished, higher education, live in rural areas or come from economically and socially disadvantaged backgrounds.

Various measures have been introduced to increase the engagement of this demographic in the labour market, such as programmes to re-train young people or increase their level of skill and competitiveness. The most recent such initiative is the 'Roadmap of Employment 2020' programme. This aims to establish education programmes, create internships and on-the-job training and create new jobs (Karibayeva, 2012). The state continuously develops the qualifications of its potential and existing labour force, with the gaps in qualified managers and experts being filled by skilled workers invited from other countries. Concurrently, inadequate training is compensated with intensive onthe job training programmes for active workers.

Once Kazakhstan gained its independence in 1991, changes were seen in the labour market as a result of the presence of certain factors, including the decline in the popu-

1 Ernst and Young (2011) Prognosis of Development of Fast-Growing Markets; Ernst \& Young (2012) Assessment of Investment Appeal of Kazakhstan; Ernst \& Young (2011) Survey of Labor Regulation Systems in Kazakhstan. 
lation; the transformation to a market economy; and the revision of laws on labour and employment.

The result of the decline in the population was that total labour resources decreased considerably.

However, another factor concerned the transformation process: prior to gaining independence, many factories and enterprises in Kazakhstan were linked with the other republics of the Soviet Union, with factories and enterprises being supplied systematically from other republics. Once the Soviet Union had collapsed, the links with the centrally-planned economy were cut apart. This would suggest that Kazakhstan was at a disadvantage once it had gained its independence; having to start everything from scratch.

Another issue which arose for Kazakhstan was the revision of laws regarding labour and employment. Early on, this encompassed protection for unemployed citizens, via the provision of money for unemployed people to use for other aims such as pension, housing and other benefits. In 2001, the third version of the employment law was adopted in Kazakhstan to provide for local labour bodies to deal with employment issues, but still the law does not address many questions about unemployment. For example, unemployment benefits and training for unemployed citizens continue to be open questions and, despite the changes in the law to help unemployed people and provide them with money for their pension, this has not really helped to resolve the issue. Many continue to suffer.

Furthermore, despite the economy in Kazakhstan being stable, and regardless of the changes that have been made in the labour market, there still remains the problem of having adequate workers. The government is experiencing increasing shortfalls in the adequate supply of workers in primary and processing industries, as well as in the service sector (in tourism, public assistance and services). One of the main issues besetting the labour market in Kazakhstan continues to be the lack of skilled and adequate workers. 
Table 5 - Kazakh GDP

\begin{tabular}{|l|c|}
\hline & GDP \\
\hline 2005 & 43.2 \\
\hline 2006 & 57.1 \\
\hline 2007 & 81.0 \\
\hline 2008 & 104.9 \\
\hline 2009 & 133.4 \\
\hline 2010 & 115.3 \\
\hline 2011 & 148.05 \\
\hline 2012 & 188.05 \\
\hline 2013 & 203.52 \\
\hline 2014 (Estimate) & 224.41 \\
\hline
\end{tabular}

Source: http://www.tradingeconomics.com/kazakhstan/gdp

Table 6 - Unemployment rate in Kazakhstan

\begin{tabular}{|l|c|}
\hline & Unemployment Rate (\%) \\
\hline 2005 & 5.2 \\
\hline 2006 & 5.2 \\
\hline 2007 & 5.2 \\
\hline 2008 & 5.2 \\
\hline 2009 & 5.2 \\
\hline 2010 & 5.2 \\
\hline 2011 & 5.1 \\
\hline 2012 & 5.1 \\
\hline 2013 & 5.1 \\
\hline 2014 (Estimate) & 5.0 \\
\hline
\end{tabular}

Source: http://www.tradingeconomics.com/kazakhstan/gdp

Tables 5 and 6 clearly show the upward trends in GDP of Kazakhstan and how the unemployment rate has gone down slightly, leading us to anticipate a negative correlation between these two series.

Informal employment is yet another issue of concern for the development of Kazakhstan's labour market. In 2009, informal employment represented about one-third of 
total employment in the country; however, the real numbers could be as high as $57 \%$ of the total labour force (Rutkowski, 2011). Among the myriad reasons for pursuing informal employment, institutional corruption, tax rates and regulations, inflation, restrictive labour regulations and policy instability rank at the top.

Illegal labour migration among post-Soviet states is a direct result of the domestic disintegration of the economic and social infrastructure and the concurrent initiatives towards intra-state integration. Labour migration in the post-Soviet region is particularly difficult to trace and measure, mostly due to the region's specificities such as a poor bureaucratic infrastructure, well-organised informal networks and ethnic enclaves that have remained after the disintegration of the Soviet Union.

Conversely, economic integration and illegal labour migration served as a 'glue' that held the post-Soviet region together during the early period, especially during the first part of the 2000s when institutional integration and diplomacy failed. Such postSoviet integration initiatives as the Eurasian Economic Community (EurAsEC or EAEC), the Customs Union (CU) and the Common Economic Space (or Single Economic Space, SEC) established the regulation of labour migration as one of their top priorities. The creation of free trade areas and common labour markets under these institutional arrangements appeared to facilitate promising prospects for the regulation of migration flows, foster the exchange of qualified workers, provide access to educational and training facilities and accommodate the exchange of knowledge and, consequently, the growth of a healthy labour force capable of answering the demands of a fast-growing economies.

\section{Comparison between Russia, Kazakhstan and Belarus}

If we look at the three countries under consideration here, we notice how labour markets play an important role in the economy of each country. The correlation coefficients discussed in this section clearly show us that the labour market and each nation's economy go hand-in-hand. In these cases, we can see how the labour market has suffered badly as a result of government neglect. We have seen that, in most cases, the governments of Russia, Belarus and Kazakhstan have tried to change laws and implement rules and regulations in order to provide assistance to the unemployed, but they have not helped this issue in the long-run, as people remain unemployed and neither do they have access to housing or pensions. Ultimately, more work is demanded of governments across the region in order to provide jobs for their people and get their economies running.

Furthermore, in reviewing the performance of the three countries we can see that a comprehensive strategy must be developed for each of the governments in creating jobs, bringing down the unemployment rate, stabilising the economy and strengthening the labour market. Table 7 shows that, as GDP or an economy shrinks or performs badly, the labour market is the first institution to feel the impact: 
Table 7 - Comparison of correlation coefficient (r)

\begin{tabular}{|l|l|c|}
\hline Countries & Variables used for calculation & Correlation coefficient $(\boldsymbol{r})$ \\
\hline Russia & GDP vs. number of Russians employed & -0.450374222 \\
\hline & GDP vs. unemployment rate & 0.2814522 \\
\hline & GDP vs. direct investment & -0.13675 \\
\hline Belarus & & \\
\hline & GDP vs. number of people employed & -0.7298 \\
\hline & GDP vs. unemployment rate & -0.95421 \\
\hline Kazakhstan & GDP vs. unemployment rate & -0.845404 \\
\hline
\end{tabular}

Note: To calculate the correlation coefficient (r), we use the following formula.

$r=n\left(\sum x y\right)-\left(\sum x\right)\left(\sum y\right) /\left(\left(n \sum x^{2}-\left(\sum x\right)^{2}\right)\left(n \sum y^{2}-\left(\sum y\right)^{2}\right)\right)^{1 / 2}$

Data are taken from http://www.tradingeconomics.com/kazakhstan/gdp

We have used here numbers from the past year, from 2013 up to the end of the second quarter of 2014, drawing on World Bank data. In order to show how important the labour market is to the economy, Table 7 depicts the values of $r$; that is, the correlation coefficient of GDP in recent years measured against a number of factors including the number of people in employment, the unemployment rate and direct investment. The value of $r$ shows us how one variable behaves when another changes and, thus, the relationship between them.

By looking at the values of $r$ in Table 7, we can see the correlation between GDP and the number of people who are employed. In Russia's case, the value of $r$ here is -0.45 . This negative correlation means that, as GDP drops, the number of people employed falls as well. The same is demonstrated by the correlation between GDP and the unemployment rate, where the value of $r$ is 0.28: a positive correlation meaning that as GDP rises, the unemployment rate falls. The same can be said about the correlation between GDP and direct investment. In this case, the value of $r$ is -0.13 . This is a negative correlation that shows that, as GDP reduces, direct investment goes down as well. Here, it is important to note that investment is only weakly correlated with GDP since a lot of investment is counter-cyclical.

Turning to Belarus, the value of $r$ in the context of the relationship between GDP and people in employment is -0.73 . This presents as a negative correlation, with a drop in GDP accompanied by a fall in employment as people lose their jobs, while the same relationship is also there in the case of GDP when set against the unemployment rate.

This shows us statistically that the labour market is an important element in the Belarusian economy. The moment an economy performs badly, the labour market is the first to feel the effects of the downwards turn in the economy. 
Looking at Kazakhstan, the value of $r$ when we review GDP and the rate of unemployment is -0.85 . This again shows a negative correlation; as we have seen in the previous cases of Russia and Belarus, just as GDP goes down, the unemployment rate goes up, i.e. the shrinking of an economy due to various factors, such as recession, indicates that the first element that will be affected is the employment rate.

In the current labour market, one of the main focuses, as correctly mentioned by Weber, Card and Kluve (2009), is the effectiveness of active labour market policies. This has been a matter of vigorous debate since there have been numerous discussions on how to make the labour market more efficient and effective. One key element is the high unemployment rate, in terms of how to bring it down and get more people back into work. Following the recession of 2007/08, creating jobs has been the main issue for many countries and this remains an ongoing process. Many people lack the training and the skills required by many of today's jobs. One current labour market policy is to create programmes for training people and preparing them in order to obtain work. Additionally, however, we might note that firms should provide employment incentives to motivate people to do their jobs better; while it is also clear that the labour market has to be better regulated and monitored so as to reduce the increase in the unemployment rate.

Each of these countries should try to regulate its labour market, stabilise the economy, create more jobs, establish financial stability in society and ensure that the pace of the economy is such that it meets the targets for sustainable growth. A conscious effort should be made by each government to strengthen the labour market in their respective country. There should additionally be an effort to make structural changes in the labour market related to employment. This includes retraining unemployed people who are looking for jobs in the current situation to provide them with the tools and the skill sets they need to meet the demands of the current job market.

There should, furthermore, be a sustainable increase in wage rates in the domestic market in these countries. This is the way forward in the future to improve economic growth and reduce inequality.

A key emphasis on mobilising and liberating the labour market will help to create more job opportunities, especially in the private sector, and there also needs to be a favourable business environment established since this is a key driver of a flourishing labour market.

\section{Conclusion}

There is no doubt that, in general, labour markets reflect upon how the economy is performing as a whole. They demonstrate how well the job market is functioning in terms of unemployment, job creation and, perhaps most importantly, the wage rate. Based on the experience of these countries in our survey, it is clear that progress has been made but, at the same time, it must be said that there remain some challenges which must be faced in the long-run, particularly related to the protection of the rights of the labour force. This has to change in order to bring about a positive change in the economy of the country.

If we look at the example of Belarus, which was a part of the Soviet Union, only a tiny fraction of its labour force, and a number significantly lower than in the Baltic 
States and in Russia, is unemployed. This is, on the face of it, a good sign for the Belarus economy. However, just like in the case of Kazakhstan, it is in the early stages of the transition from a centrally-planned to a market-based economy. Belarus will have to focus on particular areas, especially its labour market, in terms of making important reforms and ensuring that its labour force has the skills and the equipment it needs to match the demands of a market economy. The government must facilitate the reallocation of workers in all sectors and areas of the country.

Hence, for all of these countries, and including Russia, the government must allocate its resources properly in order to enhance the quality of its labour force, increase the wages of its workers, improve their level of skills, raise the living standards of its people and create jobs, and all at a minimal social cost. Protecting the rights of its workers is an essential element in the cause, as well.

All in all, the most important thing is to create a business-friendly environment in the domestic circuit of the economy, which will allow more efficient jobs to be created. This will attract foreign investors into the country and, hence, raise the standards of the working environment. This will mean greater inflows of capital into the economy which would help stabilise the domestic economy and inject reserves into the system. This would, in turn, help to improve the quality of life and create better educational institutions that are well-equipped to prepare local people in finding a job.

\section{References}

Astapenia, Ryhor (2014) Labour Market in Belarus: the Demand for Workers is increasing available at http://belarusdigest.com/story/labour-market-belarus-demand-workers-increasing-17030.

Brixiova, Zuzana and Vera Volchok (2005) Labour Market Trends and Institutions in Belarus available at: http://deepblue.lib.umich.edu/bitstream/handle/ 2027.42/40163/wp777.pdf?sequence=3

Calvo, Guillermo A, Fabrizio Coricelli and Pablo Ottonello (2012) Labor Market, Financial crisis and Inflation: jobless and wage less recoveries available at: http:// www.nber.org/papers/w18480.pdf

Daly, Mary C, John Fernald, Oscar Jorda and Fernando Nechio (2013) Labor Markets in the Global Financial Crisis available at: http://www.frbsf.org/economic-research/publications/economic-letter/2013/december/labor-market-global-financial-crisis-okun-law/

The Economist (2011) 'Labour Market Trends, Winners and Losers' available at: http:// www.economist.com/node/21528434

Ernst and Young (2011) Prognosis of Development of Fast-Growing Markets

Ernst and Young (2012) Assessment of Investment Appeal of Kazakhstan

Ernst and Young (2011) Survey of Labor Regulation Systems in Kazakhstan.

External Sector Statistics (2014), available at: http://www.cbr.ru/eng/statistics/? Prtid $=$ Svs 
Fisher, Sophy (2013) Asia-Pacific Labour Market Update available at: http:// www.ilo.org/wcmsp5/groups/public/---asia/---ro-bangkok/documents/publication/wcms_212030.pdf

Gimpelson, Vladimir and Rostislav Kapeliushnikov (2011) Labour Market Adjustment: Is Russia Different? IZA Discussion Paper No. 5588, Forschungsinstitut zur Zukunft der Arbeit (Institute for the Study of Labour): Bonn.

Heinegg, Ayo (2007) Labor Markets in Eastern Europe and Eurasia available at: http:// www.usaid.gov/sites/default/files/documents/1863/\%236\%20Labor\%20Markets \%20in\%20Eastern\%20Europe\%20and\%20Eurasia.pdf

van der Hoeven, Rolph (2010) Labour Markets Trends, Financial Globalization and the current crisis in Developing Countries available at: http://www.un.org/esa/desa/papers/2010/wp99_2010.pdf

Hofmann, Erin Trouth (2014) Eurasia on the Move: The Regional Implications of Mass Labor Migration from Central Asia to Russia available at: http://www.wilsoncenter.org/publication/eurasia-the-move-the-regional-implications-mass-labor-migration-central-asia-to-russia

International Bank for Reconstruction and Development/World Bank (2003) The Russian Labor Market: Moving from Crisis to Recovery World Bank and Izdatelstvo Ves Mir: Moscow, available at: http://siteresources.worldbank.org/INTRUSSIANFEDERATION/Resources/305499-1094736798511/518266-1095321202952/labmarket_eng.pdf

ILO (2009) Key Indicators of the Labor Market Sixth Edition.

International Labour Organization and Ministry of Health and Social Development of the Russian Federation (2011) Employment and Labor Market Strategies in Russia in the Context of the Innovation Economy available at: http://www.ilo.org/public/ english/region/eurpro/moscow/info/publ/conference2011_en.pdf

Karibayeva, Dina (2012) Kazahstan segodnya: rynok truda dlia rabotnika? (Kazakhstan Today: Labour Market for Employees?) Forbes Kazakhstan, No. 15, November.

Kuddo, Arvo (2009) Employment Services and Active Labor Market Programs in Eastern European and Central Asian Countries available at: http://siteresources.worldbank.org/SOCIALPROTECTION/Resources/SP-Discussion-papers/Labor-Market-DP/0918.pdf

Labour Force (2014) available at: http://www.gks.ru/bgd/free/b00_25/IssWWW.exe/ Stg/d000/I000040R.HTM

Pesu, Samuli (2014) Labour Market and Salaries in Russia 20.5.2014 available at: http://www.slideshare.net/AwaraDirectSearch/labor-market-and-salaries-in-russia-2014

Rutkowski, Jan (2011) Promoting Formal Employment in Kazakhstan World Bank. 
Tatibekov, Bolat L, Janet S. Adams and Nancy A. Prochaska (2004) Characteristics of the labor market and human resources management in the Republic of Kazakhstan available at: http://www.freepatentsonline.com/article/Advances-in-Competitiveness-Research/129459326.html

Tennenbaum, Jonathan (2002) Russia's Economy 1999-2001: Strong Growth, But Exhausting its Foundation available at: http://www.larouchepub.com/other/ 2002/2904russ_econ.html

Trading Economics (2014) Russia Average Monthly Wages available at: http:// www.tradingeconomics.com/russia/wages

Trading Economics (2014) Russia Employed Persons available at: http:// www.tradingeconomics.com/russia/employed-persons

Trading Economics (2014) Russia GDP available at: http://www.tradingeconomics.com/russia/gdp

Trading Economics (2014) Russia Unemployment Rate available at: http:// www.tradingeconomics.com/russia/unemployment-rate

Weber, Andrea, David Card and Jochen Kluve (2009) Active Labour Market Policy Evaluations: A meta-analysis available at http://ftp.iza.org/dp4002.pdf.

World Bank (2013) Labor Markets, Why is it Important to Evaluate? available at: http:// web.worldbank.org/WBSITE/EXTERNAL/TOPICS/EXTSOCIALPROTECTION/EXTLM/0,,contentMDK:22587483 pagePK:148956 piPK:216618 theSitePK:390615,00.html

World Bank (2014) GDP growth (annual \%) available at: http://data.worldbank.org/ indicator/NY.GDP.MKTP.KD.ZG

World Bank (2014) Labor Markets available at: http://www.worldbank.org/en/topic/ labormarkets

World of Labour Market (2012) The Labour Market in Russia available at: http:// laboureconomics.wordpress.com/2012/04/30/the-labour-market-in-russia/ 